\title{
BIBLICAL INTERPRETATION WITHIN THE CONTEXT OF ESTABLISHED BIBLE STUDY GROUPS
}

\author{
Ernst M Conradie \\ Department of Religion and Theology \\ University of the Western Cape
}

\section{Introduction}

There exists an abundant corpus of popular literature in South Africa for Bible study groups. There are also a number of publications on appropriate Bible study methods for groups. These texts often include sections on group dynamics and interaction, drawing on the equally extensive corpus of literature in psychology and sociology on the functioning of groups. In the field of theological hermeneutics the importance of interpretative communities and of "reading the Bible in communion" has often been stressed. There is no need here to repeat or to summarise the consensus emerging from such literature. There is a need though, to relate the group dynamics within Bible Study groups to the theory of Biblical interpretation. This contribution will therefore offer a few brief hermeneutical observations on the interpretation of the Bible in a group context.

\section{The purpose of Bible Study groups}

In a helpful contribution on Bible study groups, Bybelstudiegroepe: Poorte vir die genade, Coenie Burger and Nico Simpson have identified especially five main purposes for which Bible study groups meet. ${ }^{2}$ They describe these main purposes as follows:

1) A support group. One aim of Bible study groups is that of caring for one another, of offering mutual support, of praying for one another. A group may provide its members with a social and spiritual environment within which they can feel at home.

2) An integration of one's faith. Another typical aim of Bible study groups is to provide its members with an opportunity for an integration of their faith. The group activities strengthen each person's commitment to the Christian faith.

3) Deepening of insight. Some members participate in a group in the hope of gaining new knowledge of the Bible, of deepening their insight in the Christian faith, of finding new ways to think about life.

4) Commitment for service. The aim of some groups is to provide a stimulus for a variety of Christian ministries, e.g. in family life, in the congregation, in society, helping the poor, the elderly, the disabled, projects for evangelism, mission, etc. The group activities empower members for such ministries.

5) Worship and an experience of God's presence. Some groups provide their members with an opportunity of experiencing God's presence in their midst. This may emerge in activities of devotion, worship, prayer, hymns, group rituals, etc.

From this analysis it is evident that the study of the Bible is seldom the main aim of well-established Bible study groups! Many groups are not specifically interested in knowledge of the Bible, and even less in knowledge about the historical background of

1. See especially Fowl, SE \& Jones, LG 1991. Reading in communion: Scripture and ethics in Christian life. London: SPCK.

2. Burger, CW \& Simpson, N 1996. Bybelstudiegroepe: Poorte vir die genade. Kaapstad: Lux Verbi. 
specific texts. The continuation of a group's regular activities is dependent on it meeting the expectations of its members. Not surprisingly, a group's activities around the reading of the Bible and the meditation on its meaning, regularly ends in the activities which are described by its main purpose, e.g. worship, sharing with one another, supporting one another, intercession, confidence building, service, missionary outreach, developing friendships, etc.

This observation calls for some hermeneutical reflection on the dimension of application in Biblical interpretation. Since the contributions of Heidegger, Bultmann and especially Gadamer, most scholars would grant that interpretation always involves some form of application. However, interpretation as application may be understood in either a narrower or a wider sense of the word.

In a narrower sense of the word, "application" in Biblical interpretation describes the activities prompted by a specific act of (re)reading a particular text. ${ }^{3}$ One problem with such a narrower description is that direct forms of application are not often found in the activities of Bible study group. Where an act of reading the Bible does stimulate particular decisions and action, the interpretative strategy that is employed is often relatively crude and not necessarily linked to the specific text that was studied. Furthermore there may well be a gap between the decisions arrived at during the Bible study event and the actions of the group members thereafter. In this way it may be difficult to identify any form of application (except in the form of cognitive processes) that have been derived from the particular Bible study event.

In a wider sense of the word, "application" may include all activities that are directly or indirectly, consciously or sub-consciously, inside or outside faith communities, for better or for worse, influenced by previous readings of the Bible. In this use of the term, almost everything may be understood as the dimension of application in Biblical interpretation, e.g. worship, hymns, prayers, preaching, catechism, charity, fellowship, witness, ecclesial structures, church commissions, evangelism, mission, etc. - to mention only aspects directly related to the praxis of Christian communities. One problem with such a wider description is that such activities cannot be related to a reading of a specific text. They are interpretations of the Bible as a whole and the product of the accumulated influence of the Bible on church and society over centuries. In the case of individual Christians, they embody the particular person's response to the gospel over a lifetime.

In this wider sense of the notion of "application", the activities described by the purpose of Bible study groups can indeed be regarded as "interpretations" of the Bible, but scarcely of the specific text that was read. This constitutes a considerable obstacle for a hermeneutical analyst interested in the dimension of application, even though this evidently causes little dissonance for the members of the Bible study group. Perhaps analysts will simply have to accept that even the most sophisticated hermeneutical theory cannot fully account for the seemingly simple act of reading the Bible in a group context. Like the famous example of the "butterfly effect" in chaos theory, the relevant data soon becomes far too complex to monitor.

\section{Hermeneutics and group interaction}

In earlier contributions on Biblical hermeneutics, Louis Jonker and I identified seven guidelines for relatively adequate Biblical interpretation. ${ }^{4}$ These seven guidelines are related to a "map" of Biblical interpretation "that includes the following aspects:

3. See Lawrie's notion of re-inscription as discussed elsewhere in this volume.

4. See Conradie, EM \& Jonker, LC 2001. Angling for interpretation. A guide to understand the Bible better. 
1) The text itself;

2) The world-behind-the-text;

3) The history of interpretation in-front-of-the-text;

4) The spiral of appropriation and application;

5) The contemporary context(s) of the interpreter;

6) The possibility of ideological distortions from a world "below" each of these aspects.

This map is based on a simple communication model, i.e. that of the message of the text for a contemporary context. Although such a communication model may be subjected to postmodernist scrutiny for the "presence" it presupposes between two communicating subjects, it may be illuminating to analyse the complex lines of communication assumed in any Bible study event in a group context.

Let us investigate a hypothetical example of an established Bible study group of seven members reading the parable of the good Samaritan (Luke 10:25-37). One member of the group comments during the discussion that "Jesus tells us in this parable to support the government's Reconstruction and Development Programme!"

At least four axes of communication may be identified in this statement. Each of these lines of communication may be analysed rhetorically in terms of four questions: "Who says what to whom and with what effect?" At the most basic level, already assuming some intelligent guess work and reconstructions, these axes of communication may be described in the following way:

1) Jesus tells the parable of the Good Samaritan in Aramean to scribes to put them to shame for their attitude towards Samaritans, presumably with little effect on the scribes, perhaps only angering them.

2) In his gospel, "Luke" includes the story (about Jesus telling the parable to scribes) from sources available to him in order to challenge his wealthy, Greek intended readers to extend the virtue of charity to impoverished citizens. The effect on his real readers remains difficult to reconstruct.

3) In terms of the shared "world" of the contemporary Bible study group, the Holy Spirit uses the English translation of the text of Luke anew to challenge the whole group, e.g. to extend their sense of charity to fellow South African citizens in distress(?). The practical implications of this challenge may well remain vague, thus having little direct effect on the group's behaviour, except for reinforcing the virtue of charity in their interpretative "world".

4) The one group member tries to convince some of the other group members that the South African government's Reconstruction and Development Programme forms a legitimate extension of the Christian virtue of charity, presumably supported by the text of Luke 10. The response from the rest of the group will obviously be influenced by their political views and their perceptions on the viability of the Reconstruction and Development Programme.

Each of these rhetorical aspects (Who says what to whom with what effect) reveals more complex layers of meaning through further investigation. For the purposes of a

Study Guides in Religion and Theology 4. Bellville: University of the Western Cape.

5. See the contribution by Jonker on "Mapping the various factors playing a role in Biblical interpretation" elsewhere in this volume. 
hermeneutical reflection on the dynamics of Biblical interpretation in a group context, we may focus here only on the fourth of the above-mentioned axes of communication.

\section{The source:}

Several layers of meaning are possible regarding the source of the comment. Consider, for example, the following possibilities: the person may be voicing the consensus of the group; the person may be completely isolated in the group in terms of her political views; the same person may therefore want the group to acknowledge such political difference; the person may make the comment in jest; the person may be trying to draw the attention of the group on himself; the person may be speaking on behalf of an absent group member who would otherwise have made a similar comment; the person may have been instructed to drop this inuendo by his political leader; God (or even the devil?) is using the person to convey an urgent message to the group.

\section{The message:}

The parable of the good Samaritan provides an excellent illustration that the surface meaning of the message may yield many deeper (symbolic) layers of meaning. Indeed, what is the message that the parable itself conveys? Is the focus of the parable on the virtue of charity? Or on being good neighbours? Or on ethnic / religious / geographic conflict? Or on practising what one preaches? Or is it an attack on hypocrisy? The polysemy of the text yields a certain literary ambiguity that cannot be constrained into a single valid interpretation.

\section{The receiver:}

In the context of a group Bible study, the relationship between source and receiver is crucial to understand, as the above-mentioned example illustrates. These relationships are made even more complex by the impact of a wide variety of role players outside the immediate group gathered for the Bible study event. Consider the following scenarios. The group may be homogeneous, in which case the speaker's comment is meant to reinforce the existing socio-political convictions of the group. The group may be bitterly divided politically or religiously, in which case the speaker may be challenging some of the other group members (who may either be a minority or in the majority). The speaker's comment may be aimed at some of the absent group members. (Compare this with the classic example of a pastor who chides those who are not attending church in his sermon.) The speaker's comment may be aimed at people who do not share the interpretative "world" of the group, in which case the speaker may be fostering group cohesion against the perceived threat of those outside the group. On the basis of the sociological distinction between "insiders" and "outsiders", one may characterise the receivers of the message as insiders within the group, or as outsiders within the group, or as insiders outside the present group, or as outsiders outside the group.

\section{The effect of the message:}

The empirical effect of the message is not of immediate concern here. There is a range of possible intended or "implied" effects that the speaker may have evoked from the receivers of the message. These intended effects may logically include a reinforcement of existing convictions and practices, drawing new implications from them, the suggestion of innovations to them, or an outright rejection of them. Going back to the example above, we may consider the following possibilities: The speaker may be voicing group consensus in 
which case the intended effect will be a reinforcement of existing beliefs and practices. The speaker may wish to show the other group members that she does not share the political views of the rest of the group. The person may want to make a clever contribution to the discussion to gain honour from the rest of the group. The person may want to foster group cohesion against outsiders who do not share their views. In an extreme case (!) the person may actually be encouraging members to help in a local Reconstruction and Development Programme.

This analysis only takes account of a single axis of communication, i.e. between the source and the receiver(s). The actual responses from group members are not yet taken into account. The other members of the group may nod approval, shake their heads, make further contributions in this regard, ignore the comment, or redirect the conversation to something else which is of more concern to them.

Each response will constitute a new axis of communication and a reconfiguration of the symbolic worlds involved in that communication. It should be clear that any structural analysis of such communication will soon become far too complex to be of any value. Hermeneutical analysis therefore has to focus on specific salient features of the conversation in a Bible Study group. In this respect, hermeneutical analysis requires considerable skill. Like interpretation, it is an art that cannot be mastered by following methods or recipes rigidly.

\section{The hermeneutical effect of group cohesion}

Bible study groups have to maintain some form of group cohesion in order to survive as a group. Members of the group will only attend meetings if there is a clear focus on the purpose for which the group regularly meets. Maintaining group cohesion is usually the task of the group leader. Group members may also refrain from making certain comments for the sake of group solidarity. This need for group cohesion constitutes one of the ways in which the activities of the group constitute more than the sum total of the interactions between its members. The group also reads and interprets the Bible as a group.

The need for group cohesion has a multiple effect on the process of interpretation.

- The reading of Biblical texts in a group context often appears highly generalized. Particular texts are regarded as examples of well-known types. The text is only allowed to say something that the group is already familiar with. In this way the expectations of the group are almost always confirmed. This may be the result of the need for a reinforcement of the group's dominant heuristic keys. It may also follow from the emotional need for group cohesion.

- Bible study groups are, as a result, seldom good close readers of a text. There is often little sensitivity to literary structure, genre, literary context, polysemy and style. The strangeness or otherness of the text is not always recognised. Groups tend to avoid the unfamiliar, the problematic, the contradictory, the ambiguous, in order to focus on something that would be "safe" enough not to threaten the cohesion and purpose of the group.

- Bible Study groups are often less interested in historical questions about "what the text has meant" (and thus the historical background of the text) and more in what the text means within their own context. There is a tendency to assimilate the "world" of the Bible (its narratives, characters, topography, symbols, themes, etc) within the group's own interpretive world. The larger frame within which a text is interpreted is usually not historical but doctrinal or moral (rules, laws, principles). Often, the text is simply regarded as another example of Christian life. 
- Groups tend to appropriate the meaning of the text for their own context in the most direct possible way. The strategy of identifying abiding doctrinal truths or moral principles in the text serves this purpose particularly well. Doctrines and moral principles offer certain rules (of faith and of life) to the group with a reassuring familiarity, simplicity, directness and clarity. Even doctrines are often re-inscribed as rules (e.g. "We must remember that ..."). This moralising interpretative strategy favours a confirmation, reassurance, and reinforcing of a group's existing beliefs, values and practices. Although one of the expressed purposes of many groups is that of growth, there is often little room for new insights to emerge (e.g. Today I learned that ..."; or "Now I see things in a different light.")

\section{Conclusion}

Bible study within a group context is an extremely complex event in which the Bible is read by individuals (often in response to one another) as well as by the group as a whole. Each of the individual members brings his or her own context, history and interpretative world into the Bible study while established Bible study groups soon develop a history and ethos of their own. 